\title{
Use of Ubp1 protease analog to produce recombinant human growth hormone in Escherichia coli
}

\author{
Anna Wojtowicz-Krawiec ${ }^{1 *}$, Iwona Sokolowska ${ }^{1 \dagger}$, Maria Smorawinska ${ }^{1}$, Luiza Chojnacka-Puchta ${ }^{1}$, Diana Mikiewicz ${ }^{1}$, \\ Natalia Lukasiewicz', Alina Marciniak-Rusek', Renata Wolinowska², Anna Bierczynska-Krzysik', \\ Anna Joanna Porebska', Jolanta Kuthan-Styczen', Lidia Gurba', Piotr Borowicz', Anna Mazurkiewicz' , \\ Grazyna Plucienniczak ${ }^{1}$ and Andrzej Plucienniczak
}

\begin{abstract}
Background: Numerous bacterial human growth hormone $(\mathrm{hGH})$ expression methods under conventional fermentation and induction conditions have been described. Despite significant progress made in this area over the past several years, production of recombinant hGH by using cellular expression systems still requires further optimization. Fusion of the ubiquitin (Ub) tag to the hGH protein allowed to increase of the overall efficiency of the biosynthesis and improve the protein stability. Ub is a protein composed of 76 amino acid residues with a molecular mass of $8.6 \mathrm{kDa}$, expressed in all eukaryotes. This protein is an element of the universal protein modification system, which does not occur in bacteria, and is a useful carrier for heterologous proteins obtained through expression in Escherichia coli. Purification of Ub-fusion proteins is easier than that of unconjugated recombinant proteins, and Ub can be removed by deubiquitinating proteases (DUBs or UBPs).

Results and Conclusion: In the present study the UBPD2C protease, a stable UBP1 analog, was produced as a recombinant protein in E. coli and used for production of recombinant human growth hormone (rhGH). hGH was expressed as a fusion protein with Ub as a tag. Our findings show that the UBPD2C protease is very effective in removing the $\mathrm{Ub}$ moiety from recombinant $\mathrm{Ub}$-fused $\mathrm{hGH}$. The described approach enables obtaining a considerable yield of rhGH in a purity required for pharmaceutical products.
\end{abstract}

Keywords: Recombinant human growth hormone, Ubiquitin, Deubiquitinating protease, Protein expression

\section{Background}

UBP1 protease is a yeast cysteine protease, 809 amino acids long, which cleaves ubiquitin from proteins fused to its C-terminus [1], and binds to Ub through an ester bond during the reaction. The protease activity depends on its ability to cleave the Ub peptide fused via its C-terminus to other polypeptides, regardless of the amino acid sequence of the fused moiety [2].

In some expression systems, proteins of interest are first expressed as fusions with Ub [3] or its derivatives [4-10], and then recovered using an Ub-removing enzyme (e.g. UBP1)

\footnotetext{
* Correspondence: wojtowicza@iba.waw.pl

${ }^{\dagger}$ Equal contributors

'Institute of Biotechnology and Antibiotics, Staroscinska 5, Warsaw 02-516, Poland

Full list of author information is available at the end of the article
}

$[11,12]$. This approach has many advantages, including improved quality and efficiency of protein expression as well simplified purification process, which are of great importance in the industrial production of recombinant proteins [13-18]. We previously described [19] UBP1 protease deletion and point mutations, which improved the expression level of the protease in a microbiological expression system [20].

In technological processes, large quantities of deubiquitylating enzyme (DUB) are required for maximum possible catalytic activity. However, the majority of the currently available expression protocols does not lead to efficient expression of DUB, which greatly limits their applicability, especially in industrial processes. In the production of a specific protein for therapeutic application, 
particularly human growth hormone (hGH), purity and activity of the enzymes used are important factors. Accordingly, we have presented various solutions to meet these requirements $[19,20]$. Nevertheless, there is still a need for a method to obtain highly active DUB enzyme in a gram-scale quantity for the production of bioactive peptides $[4,5,21]$.

In the present study, we describe the development of an efficient method for obtaining hGH from bacterial cells, particularly from Escherichia coli. This method could yield gram-scale quantities of the protein with appropriate activity for application in the production of pharmaceutical preparations.

\section{Human growth hormone}

$22 \mathrm{kDa} \mathrm{hGH}$, also known as somatotropin, is a single chain polypeptide consisting of total 191 amino acids $[22,23]$. It is synthesized and secreted by cells known as somatotrophs in the anterior pituitary. In the lifetime of an individual, the highest quantities of growth hormone are produced during puberty in the anterior lobe or glandular portion of the pituitary [24-28]. hGH is synthesized as a precursor and released into the blood following post-translational modifications. The hormone is used in the treatment of certain forms of dwarfism caused by hGH deficiencies, in obesity therapy, and in wound and burn treatment. Clinical trials indicate that hGH helps diminish the devastating effects of the hypermetabolic response to burn injury especially among children. These are the reasons why the demand for this hormone is very high [29-33].

Production of recombinant hGH requires optimization of vectors used to express the protein in those heterologous hosts. A series of methods have been designed [8,34-39]. A generic expression vector features promoter sequences facilitating transcription and translation as well as sequences ensuring the stability of the synthesized protein. The vector described in this study contains strong promoters that enable efficient synthesis and accumulation of $30 \%$ or more of the targeted recombinant proteins among the total cellular proteins. In this study, we have reported the cloning, expression, refolding, and purification of hGH.

\section{Results and discussion}

\section{The Ub tag was used to obtain a mature form of hGH}

$\mathrm{Ub}$, the best-known short protein, was used as the tag in this study. The use of Ub to enhance the levels of protein expression has been reported previously [4,13,14,40-43]. In the present study, efficient expression of the Ub::hGH fusion gene in $E$. coli strains was achieved, and the UBPD2C analog of the UBP1 protease was used to cleave the Ub moiety from the N-terminus of the hGH. The hybrid polypeptide gene was cloned into several expression vectors such as pIGAL1, pIGDM1, pIGRKAN, and pIG MS31KAN. The resulting plasmids pIGDMKUH, pIG ALUH, pIGALUHM, pIGRKKhGH, and pIGMS31PRH were used to transform E. coli strains DH5 $\alpha$ and NM522. The E. coli DH5 $\alpha$ cells were found to be most suitable with regard to the expression level of this fusion gene and the protein purification process. We used several vectors to determine the most suitable one, and the differences between them have been described in the Materials and methods section. The above-mentioned expression vectors with constitutive promoters pms or P1, P2 and terminators T1, $\mathrm{T} 2$ and pms (in appropriate combinations) were used. All of the constructed $E$. coli strains carried one of the following plasmids: pIGDMKUH, pIGALUH, pIGALUHM, pIGRKKhGH, or pIGMS31PRH, and were tested according to the procedure briefly presented in Figure 1.
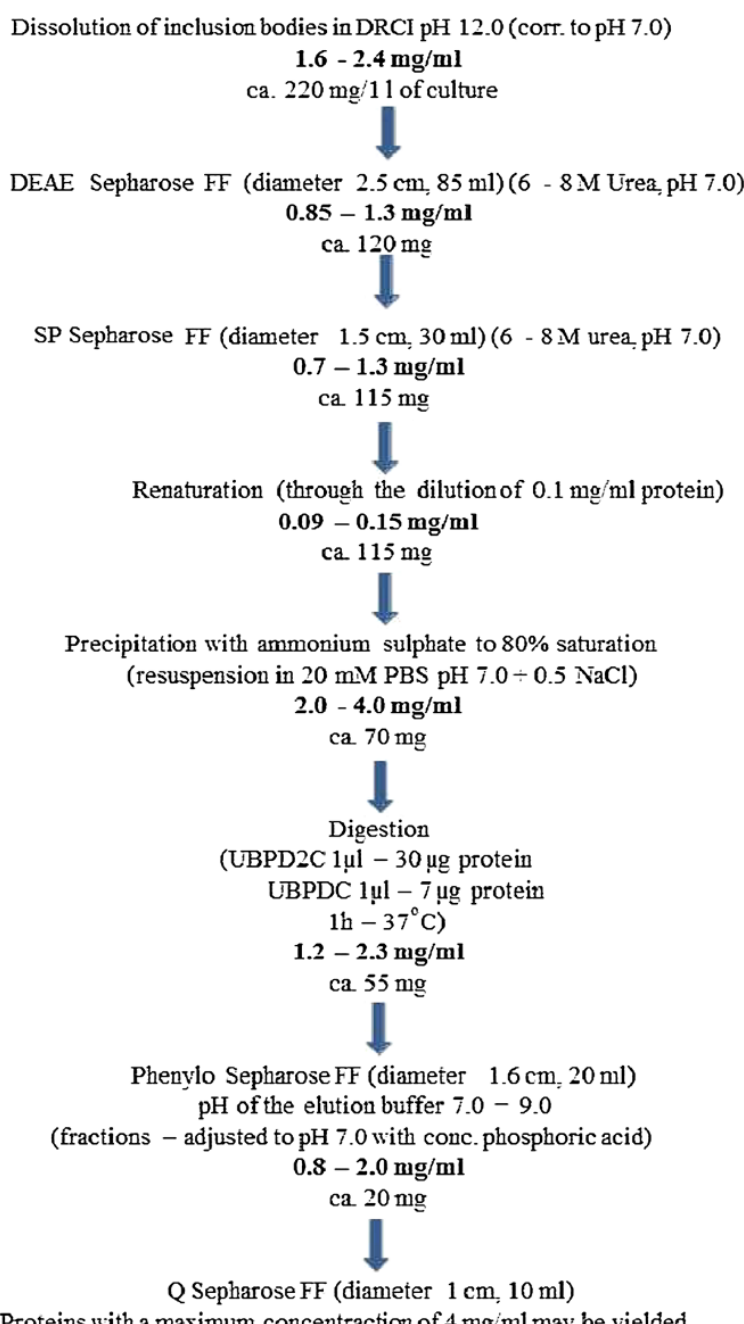

Proteins with a maximum concentraction of $4 \mathrm{mg} / \mathrm{ml}$ may be yielded ca. $20 \mathrm{mg}$

Figure 1 Schematic showing the steps involved in the purification of the growth hormone. The values obtained for selected parameters of the process as well as the protein yields are indicated. 
The scheme presented in Figure 1 summarizes the workflow after harvest of the inclusion bodies: purification of Ub::hGH by chromatography on SP Sepharose FF column, renaturation, protein precipitation and cleavage of Ub from Ub::hGH fusion protein. Purification of hGH was performed on Phenyl Sepharose FF column and then the protein was concentrated on Q Sepharose FF column. The purity of the preparations at each stage of purification was monitored via SDS-PAGE (Figures 2 and 3).

\section{Ub::hGH cleavage by UBPD2C-the UBP1 analog}

The time course of $\mathrm{Ub}: \mathrm{hGH}$ fusion protein digestion by the UBP1 protease analog was analyzed. Aliquots of the

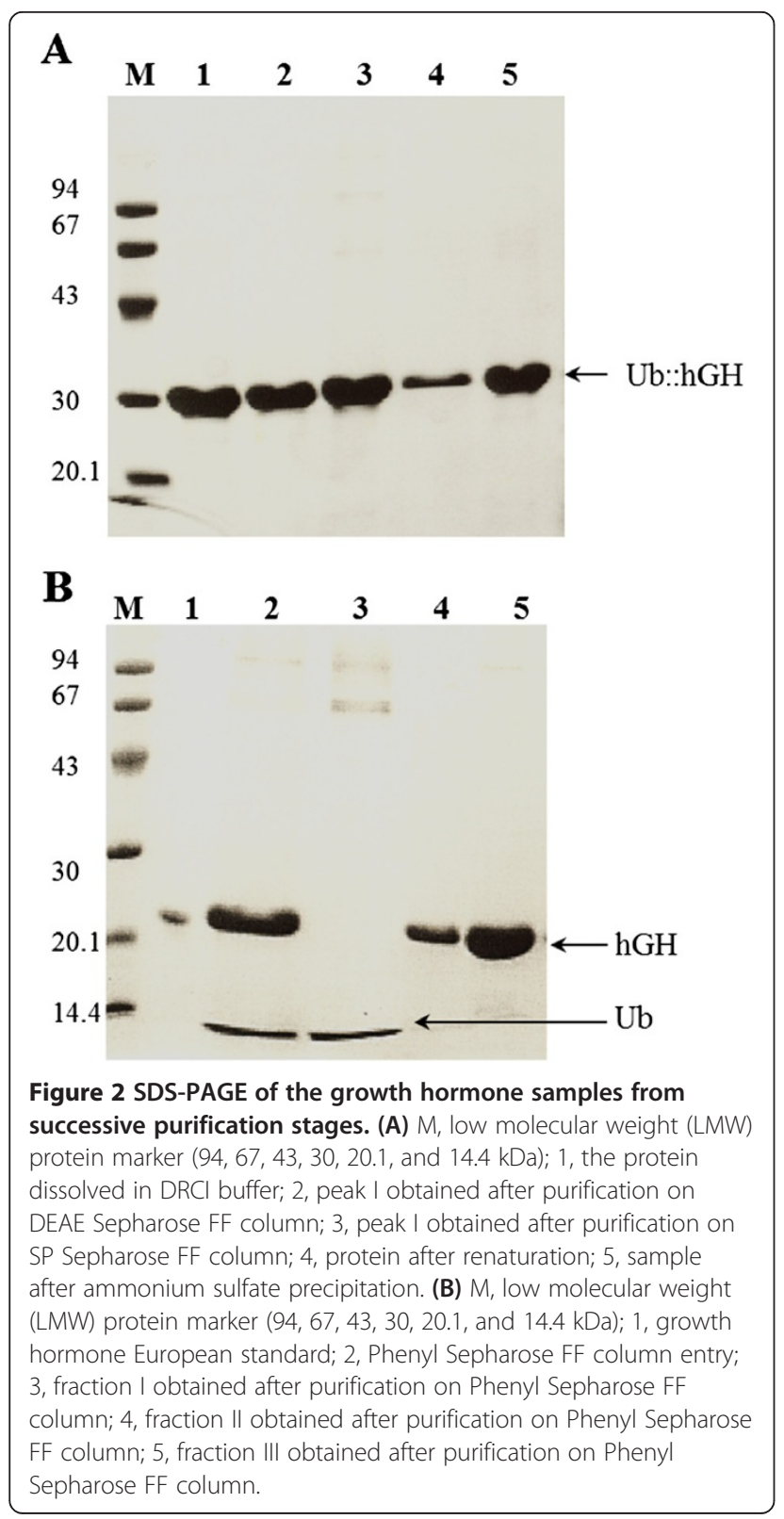

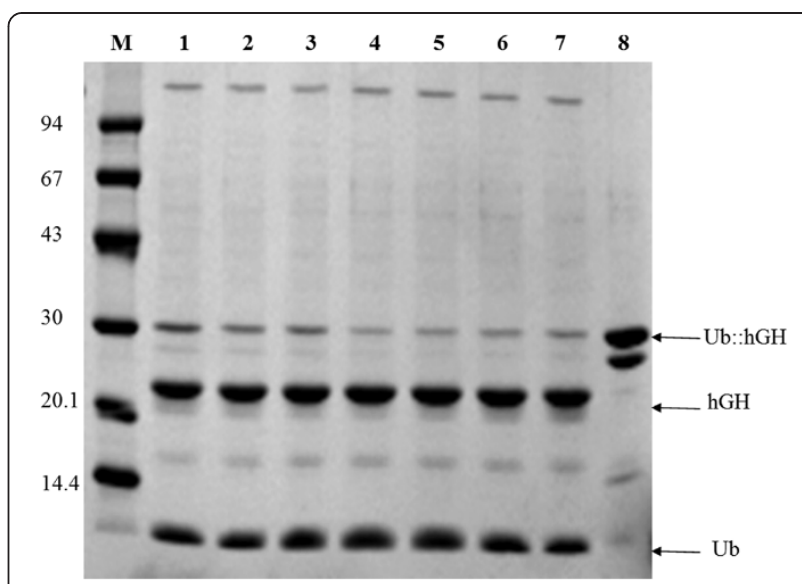

Figure 3 SDS-PAGE of Ub::hGH fusion protein cleaved by UBPD2C protease: M, low molecular weight (LMW) protein marker $(94,67$, 43, 30, 20.1, and $14.4 \mathrm{kDa}$ ); 1, 10-min digestion; 2, 15-min digestion; 3 and 7, 30-min digestion; 4, 40-min digestion; 5, 50-min digestion; 6, 60-min digestion; 8, standard Ub::hGH.

reaction mixture were collected at different time points and resolved by SDS-PAGE (Figure 3). It can be clearly seen from the figure that most of the Ub:hGH was converted to hGH already after $10 \mathrm{~min}$. The reaction proceeds up to $40 \mathrm{~min}$. From that point the intensity of the Ub::hGH band does not change indicating termination of the cleavage.

The stability of the UBPD2C enzyme prepared in an earlier study [19] was further investigated. The UBP1 protease analog was incubated for $22 \mathrm{~h}$ at temperatures of $4^{\circ} \mathrm{C}, 20^{\circ} \mathrm{C}, 25^{\circ} \mathrm{C}$ and $37^{\circ} \mathrm{C}$, respectively. Subsequently, each of these test preparations was used for digesting the Ub::hGH fusion protein under the conditions described in the Materials and methods section. Aliquots of the samples collected at different time points were analyzed by SDS-PAGE. As shown in Figure 4, the

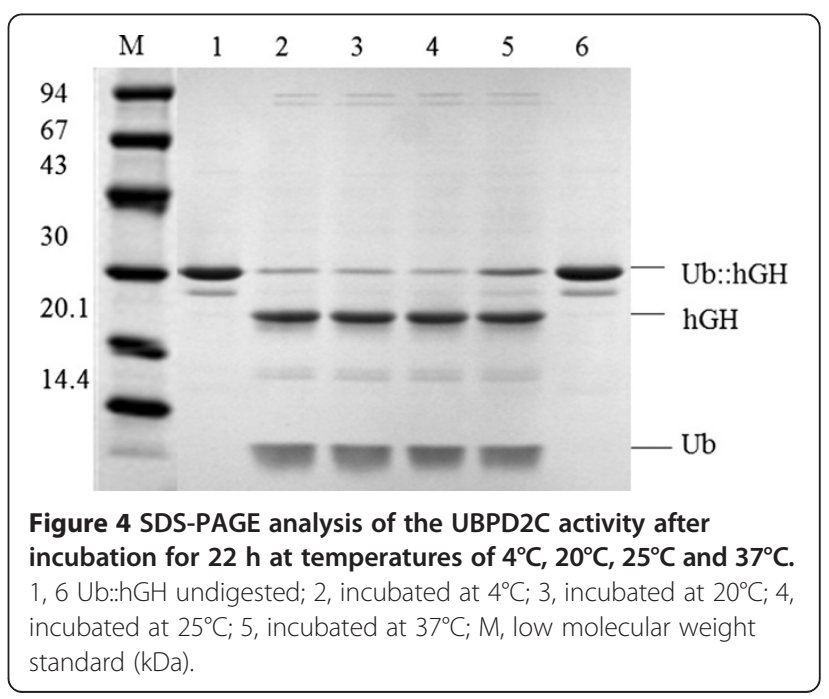


protease was stable at all the different temperatures tested (Figure 4).

Furthermore, the stability of the purified UBP1 analog protease was also tested by storing aliquots of the samples at $20^{\circ} \mathrm{C}, 4^{\circ} \mathrm{C},-4^{\circ} \mathrm{C}$ and $-20^{\circ} \mathrm{C}$ for 25 weeks. Subsequently, standard digestion procedure using the Ub::hGH purified substrate was carried out and the extent of cleavage was assessed by SDS-PAGE, followed by densitometric quantification of the reaction products (GelScan v. 1.45). The results of this analysis, shown in Figure 5, clearly demonstrated that UBPD2C enzyme can be stored for 25 weeks at $-20^{\circ} \mathrm{C}$. If stored at $4^{\circ} \mathrm{C}$ it is completely inactivated after 2 weeks and at $-4^{\circ} \mathrm{C}$ after 3 weeks. Incubation of the protease at $20^{\circ} \mathrm{C}$ for three days allowed to retain $50 \%$ of its activity. After 1 week in this temperature it became completely inactivated. Protease stored at $-70^{\circ} \mathrm{C}$ remained active for 25 weeks (data not shown). The enzyme is capable working in a wide range of $\mathrm{pH}$ (from $\mathrm{pH} 10.0$ to $\mathrm{pH}$ 6.0) and temperature (from $15^{\circ} \mathrm{C}$ to $50^{\circ} \mathrm{C}$ ) (data not shown).

Final preparations of the hGH purified from the five tested $E$. coli strains were analyzed by high-performance liquid chromatography (HPLC) using the method described in the European Pharmacopoeia $\left(5^{\text {th }}\right.$ Edition, 2005) [44]. Accordingly, E. coli DH5 $\alpha$ cells carrying the pIGDMKUH plasmid were found to be the best construct for obtaining hGH. The hGH preparation obtained from this strain and purified according to the method described earlier exhibited approximately $92.2 \%$ purity, thus fulfilling the specifications/conditions required by United States Pharmacopeial Convention [45] and European Pharmacopoeia ( $7^{\text {th }}$ Edition, 2010) [44] (Table 1). Accordingly, in order to monitor the size of molecules present in the Ub::hGH UBPD2C digest and hGH after Phenlyl Sepharose FF Column, size exclusion chromatography (SEC) was performed (data not shown, please refer to the Figure 1 in the manuscript, showing the steps involved in the purification of the growth hormone). The protein purity analysis allowed to observe a significant improvement in hGH purity by removal of high and low molecular weight impurities present in the digest.

\section{Analysis of the stability of various hGH expression constructs in E. coli DH5a cultures grown in an antibiotic- free LB medium}

Stability experiments were conducted according to the above-described method using the E. coli DH5 $\alpha$ host strain with various expression vectors: pIGMS31PRH, pIGRKKhGH, pIGDMKUH, pIGALUH, pIGALUHM.

SDS-PAGE and phase contrast microscopy revealed that the most stable plasmids used for the transformation of E. coli DH5 $\alpha$ cells was pIGDMKUH. The plasmid was found to remain stable through 80 generations (four passages) in antibiotic-free cultures (Figure 6). This finding is important for the use of the protein in the pharmaceutical industry.

Production of hGH through fermentation using organisms transformed by recombinant hGH expression constructs requires optimization of vectors used to express the proteins of interest in those heterologous hosts. A generic expression vector features promoter sequences facilitating transcription and translation as well as sequences ensuring the stability of the synthesized protein. The vectors described in this study contained strong promoters that could direct efficient synthesis and accumulation of $30 \%$ or more of recombinant proteins among the total cellular proteins. Each construct was different with respect to the kind of promoter used or its orientation or transcription terminator or resistance

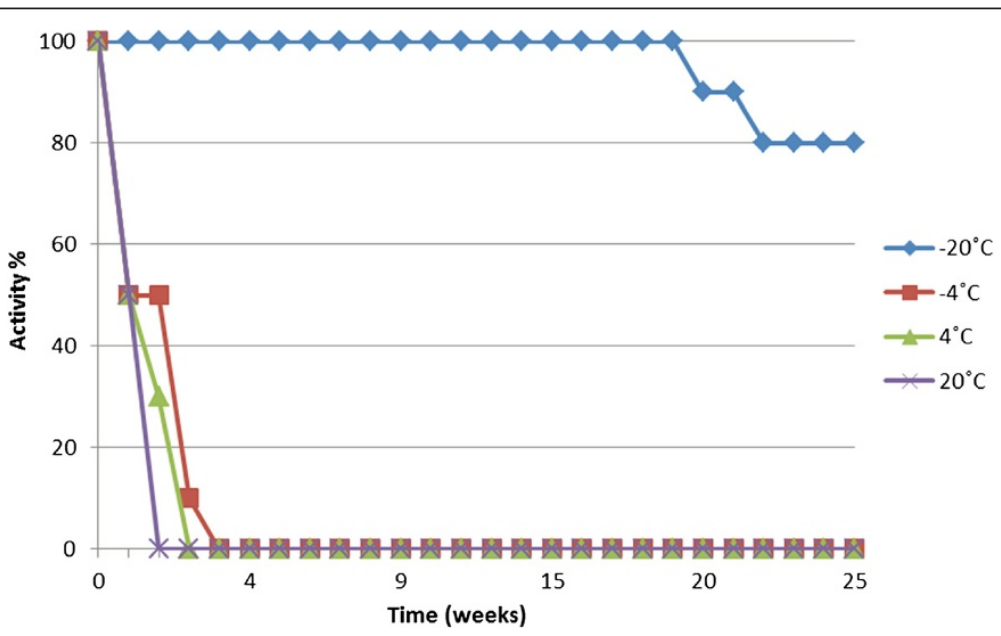

Figure 5 Stability of UBPD2C protease. Stability of UBP1 protease measured every week after incubation of this enzyme at $+20^{\circ} \mathrm{C},+4^{\circ} \mathrm{C},-4^{\circ} \mathrm{C}$ or $-20^{\circ} \mathrm{C}$. The first measurement of UBP1 protease activity incubated at $+20^{\circ} \mathrm{C}$ followed after 3 days. 
Table 1 Results of culturing, isolation of inclusion bodies, and chromatographic purification of hGH from E. coli DH5a cells carrying the pIGDMKUH plasmid

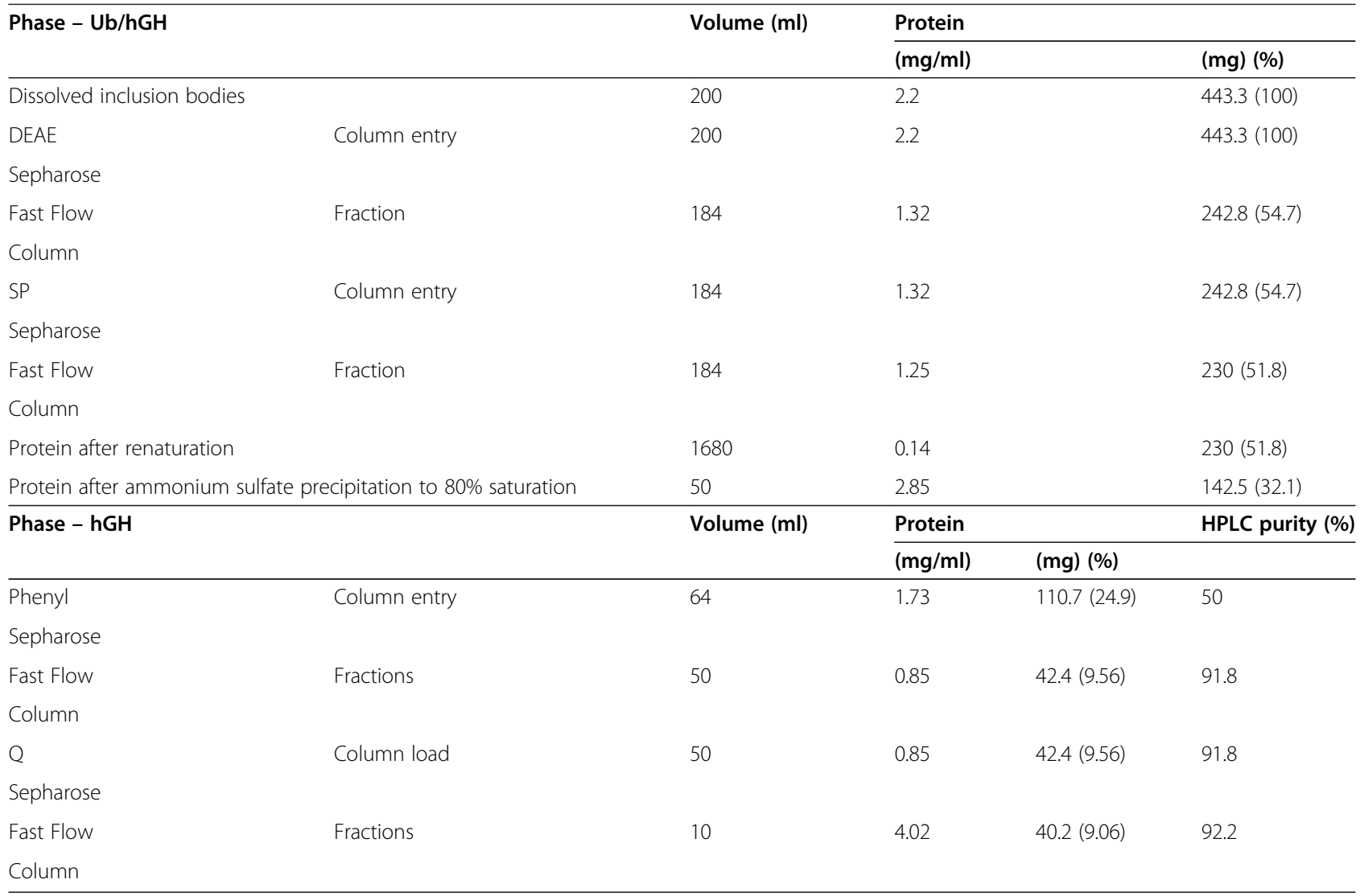

to antibiotics. These were the main variations leading to selection of one final vector construct enabling most efficient recombinant hGH expression.

In many cases the overall yield of biologically active protein is very low, and the methods of purification hGH are often not efficient or time-consuming. An alternative approach that has been developed involve complete solubilization and purification of rhGH produced in E. coli. [34]. Kim et al described obtaining of hGH and His-hGH expression by inducing IPTG and purifying them on the Ni-NTA column. The other work [46] described seven N-terminal fusion partners His6, Trx, GST, b' and a' domain of PDIb' a', NusA, PDI for soluble overexpression of hGH in E. coli. To cleave the tag proteins from fused $\mathrm{hGH}$, the TEVrs protease was used. The tobacco etch virus recognition site ENLYFQ/G was placed at the N-terminus

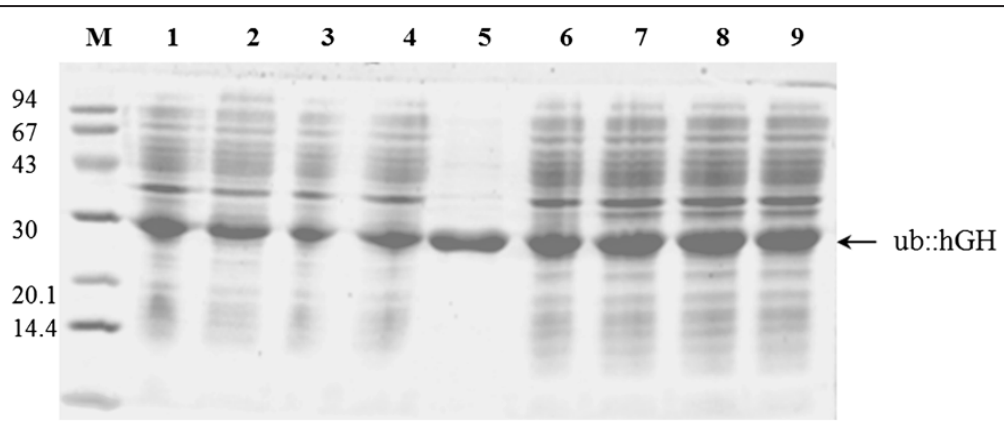

Figure 6 SDS-PAGE assessment of the stability of the pIGDMKUH plasmid in E. coli DH5a cells. Every passage was cultured for $18 \mathrm{~h}$. M, low molecular weight standard $(94,67,43,30,20.1$, and $14.4 \mathrm{kDa}) ; 1,1^{\text {st }}$ passage of culture with antibiotic pressure; $2,2^{\text {nd }}$ passage of culture with antibiotic pressure; $3,3^{\text {rd }}$ passage of culture with antibiotic pressure; $4,4^{\text {th }}$ passage of culture with antibiotic pressure; 5 , purified Ub::hGH as control; $6,1^{\text {st }}$ passage of culture without antibiotic pressure; $7,2^{\text {nd }}$ passage of culture without antibiotic pressure; $8,3^{\text {rd }}$ passage of culture without antibiotic pressure; $9,4^{\text {th }}$ passage of culture without antibiotic pressure. 
of hGH. In this case, only the DNA sequence was changed rather than amino acids. We tried to obtain hGH with a native growth hormone sequence for medical/pharmaceutical application.

In addition to the above-mentioned analyses, HPLC purification, sequencing of the $\mathrm{N}$-terminus (15 amino acid residues; performed at Biocenter Kraków), and mass spectrometry of the purified preparation were performed to confirm that the protein is hGH.

\section{Biological activity of rhGH}

To determine the biological activity of the obtained rhGH, the protein was allowed to stimulate mitosis, and then tetrazolium salt (MTT) was added to determine the number of live cells. In this method, active mitochondrial dehydrogenases in the live cells changed the yellow color of the MTT to a purple product of formazan with a concentration proportional to the number of live cells.

This method allowed the examination of the biological activity of the rhGH preparation, and confirmed that proper tertiary structure of the protein had been obtained. The calculated biological activity of the preparation was 4.4 IU/mg and that of the somatotropin standard was $2.0 \mathrm{IU} / \mathrm{mg}$. The rhGH protein purified under our conditions retained its biological activity at the comparable level to that of control hGH. In contrast, no growth stimulation was observed with BSA, which was used as a negative control (Figure 7).

Once satisfactory yield of purified hGH was obtained from $1 \mathrm{l}$ of bacterial culture, the process was further scaledup and the growth hormone was produced on a large scale (data not shown). Usage of 150 liter fermentor enabled to achieve the production capacity of $250 \mathrm{~g}$ per year.

\section{Conclusions}

The purpose of this study was to develop an efficient method for obtaining recombinant hGH from $E$. coli. We showed that the strains of $E$. coli, transformed with expression plasmids carrying the Ub-growth hormone gene, yielded satisfactory expression of the Ub-growth hormone protein in LB medium. In each case, most of the Ub-growth hormone fusion protein was produced in the inclusion bodies. The efficiency of protein expression was found to be sufficiently high, enabling the developed strains of $E$. coli to be used for industrial-scale production of hGH (220 mg of inclusion bodies/1 l of culture). This method could facilitate the production of relatively large quantities of the protein with appropriate quality (purity: $92.2 \%$ ) and activity (4.4 IU/mg while the standard reached $2.0 \mathrm{IU} / \mathrm{mg}$ ) and application in pharmaceutical industry.

Furthermore, another purpose of this study was to establish a protocol for growth hormone purification, in particular, the renaturation conditions. Accordingly, it was found that the UBP1 protease analog is a flexible tool that may be successfully used in experimental research as well as in the manufacture of recombinant proteins.

To summarize, the use of the above-mentioned system (expression of the final substrate in the form of Ub::hGH fusion protein and the use of UBP1 analog protease for deubiquitination), exploiting a highly specific and stable protease allows retrieving the required protein with high yield. $20 \mathrm{mg}$ of the purified hGH was obtained from 11 of bacterial culture. These properties make it suitable for a large-scale production in the pharmaceutical industry. Moreover, it must be noted that the E. coli DH5 $\alpha$ strain

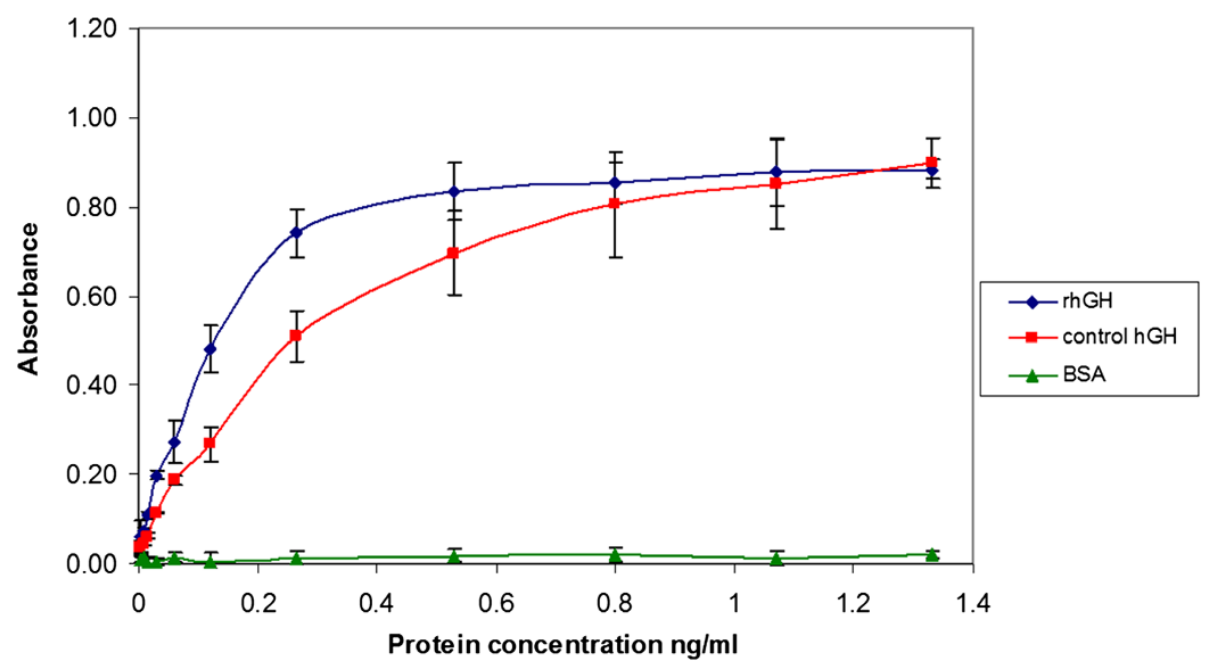

Figure 7 Results of the measured biological activity of the prepared rhGH obtained with the use of KC Junior program in ELISA MQuant Bio-Tek Instruments. ( $\mathbf{a})$ control hGH (somatotropin) curve; $\$$ ) curve for absorbance vs. rhGH protein concentration in the preparation and $(\boldsymbol{\Delta})$ BSA at the indicated concentration. 
with pIGDMKUH plasmid was the most efficient construct, which remained stable and facilitated bacterial growth in the absence of any antibiotic.

\section{Materials and methods}

\section{Primers, plasmids, and bacterial strains}

The UBPD2C protease gene was obtained as described previously [19,20], [47]. The Ub::hGH fusion gene was cloned into plasmid pIGCMST derivative [48] using restriction enzymes, NdeI and SalI. The recombinant plasmid was named pIGCMUHGH and was deposited in GenBank (Accession No. HQ845201) [49].

The pIGCMUHGH plasmid was used as a template for PCR. The hGHubF and hGHubF primers were used (Table 2) to amplify the Ub::hGH sequence. The amplified 450-bp DNA fragment was purified using a DNA gel extraction kit (A\&A Biotechnology, Gdansk, Poland), and was digested with $\mathrm{NdeI}$ and SalI and subcloned into pIGMS31KAN, pIGRKKAN, pIGDMKUH, pIGALUH, and pIGALUHM expression vectors. Each of the obtained plasmids was sequenced to confirm the identity of the DNA sequence. Subsequently, these plasmids were transformed into E. coli strain NM522. The genotypes of the bacterial strains used in this study are listed in Table 3. The strains were grown in Luria-Bertani (LB) medium as described previously [50].

\section{Construction of expression vectors pms promoter and deo P1 P2 promoter}

The pms promoter was isolated from a plasmid present in a clinical strain of Klebsiella pneumonia (GenBank Accession No. AY543071) [49,50]. It is a strong, constitutive promoter (Patent PL 213561). The sequence of the deo P1P2 promoter/operator region is known and the entire deo P1P2 promoter region is approximately 760 bp long, with the two promoters being separated by a distance of about $600 \mathrm{bp}$. Expression of a gene product under deo P2-driven transcription is very low in the presence of glucose and very high in the presence of other energy producing sources. Initiations from P1 are negatively controlled by the deoR repressor, the inducer being deoxyribose-5-phosphate (deoxyribose-5-P). Initiations from P2 depend on the cyclic AMP/cyclic AMP

Table 2 Nucleotide sequences of primers used for PCR and construction of Ub::hGH fusion gene

\begin{tabular}{llll}
\hline Name of primer & $\begin{array}{l}\text { DNA sequence (restriction } \\
\text { sites underlined) }\end{array}$ & $\boldsymbol{T}_{\mathbf{m}}\left({ }^{\circ} \mathbf{C}\right)$ & $\begin{array}{l}\text { Restriction } \\
\text { site }\end{array}$ \\
\hline hGHubF & $\begin{array}{l}\text { GGGGCCGCGGTTCCCAACC } \\
\text { ATTCCCTTAAGTAGGC }\end{array}$ & 57 & R.SaCll \\
hGHubR & GGGGGTCACTTAGAAGC & 58 & R.Sall \\
& CACAGCTGCCCTCC & & \\
\hline
\end{tabular}

Table 3 Bacterial strains used in this study

\begin{tabular}{|c|c|c|}
\hline Strains & Genotype & Source \\
\hline E. coli NM522 & $\begin{array}{l}F^{-} \text {proA }+B+\text { laclq } \Delta(\text { lacZ)M15/A(lac-proAB) } \\
\text { glnV thi-1 } \Delta(\text { hsdS-mcrB)5 }\end{array}$ & Stratagene \\
\hline E. coli DH5a & $\begin{array}{l}F^{-}, \Phi 80 \text { dlacZ } \Delta M 15 \Delta(\text { lacZYA-argF } U 169 \text {, deoR, } \\
\text { recA1, endA1, hsdR17(rK- mK+), supE44, } \lambda-\text {, } \\
\text { thi-1, gyrA96, relA1 }\end{array}$ & Novagen \\
\hline
\end{tabular}

receptor protein complex (cAMP/CRP) and are negatively controlled by the cytR repressor, the inducer being cytidine [51].

\section{pIGMS31KAN plasmid}

The promoter sequence of retron Ec86 and its following transcription terminator sequence [52] were inserted into pIGMS31KAN plasmid. The resulting pIGMS31PR plasmid was used to clone the Ub::hGH fusion gene (Figure 8).

\section{pIGRKKAN plasmid}

P1 and P2 deo operon of E. coli strain K-12 promoters, and the gene encoding the fusion protein composed of synthetic $\mathrm{Ub}$ and the gene growth hormone in R.NdeI and R.SalI restriction sites were cloned into pIGRKKAN plasmid, which was isolated from $K$. pneumonia strain 287-w. The restriction map of the recombinant plasmid is presented in Figure 8.

\section{pIGDMKUH plasmid}

The pIGDMKUH plasmid was derived from pIGDM1 plasmid (GenBank Accession No. AF014880) [49]. The length of the pIGDMKUH plasmid was $3887 \mathrm{bp}$ and contained the pms promoter and T1, T2 transcription terminators [53]. The synthetic Ub::hGH fusion gene was cloned into R.NdeI and R.SalI sites (Figure 8).

\section{pIGALUH and pIGALUHM plasmids}

The pIGALUH and pIGALUHM plasmids were derived from pIGAL1 plasmid (GenBank Accession No. AY424310). The synthetic Ub::hGH fusion genes were cloned into the pIGALUH and pIGALUHM plasmids. The pIGALUH plasmid contained the ampicillin resistance gene, pms promoter, and terminator sequences, while the pIGALUHM plasmid contained the ampicillin resistance gene, pms promoter in reverse orientation, as well as an additional transcription terminator located upstream of the pms promoter (Figure 8).

\section{Creating bacterial glycerol stocks for long-term storage of plasmids}

The method of preparing bacterial stocks is critical for maintaining efficient expression and plasmid stability in host cells. One bacterial colony was inoculated into $3 \mathrm{ml}$ 


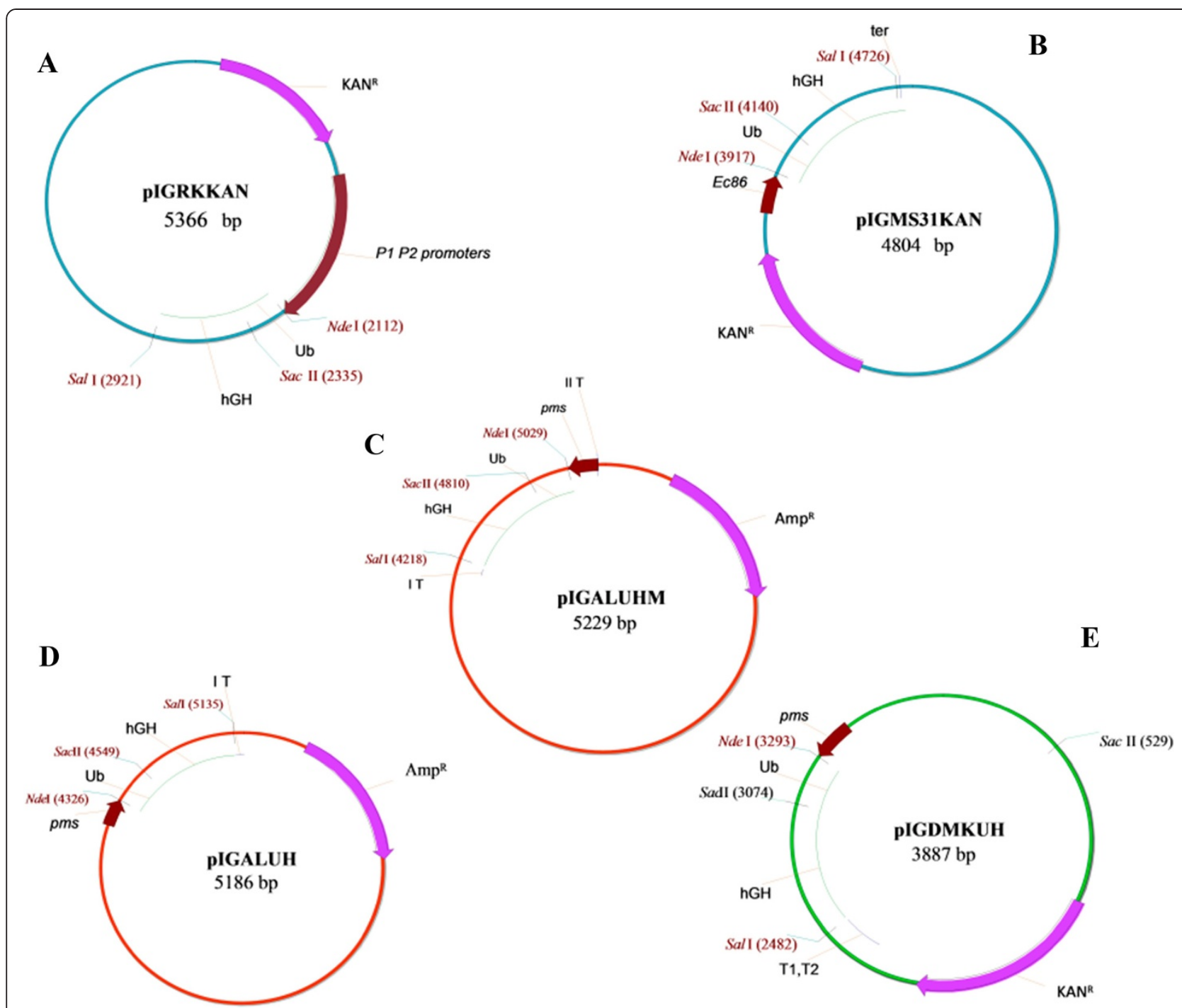

Figure 8 Schematic representation of the expression vectors A-pIGRKKAN, B-pIGMS31KAN, C-pIGALUHM, D-pIGALUH and E-pIGDMKUH. hGH was expressed as a fusion protein with the Ub tag. The restriction enzyme sites used to clone the Ub::hGH gene are indicated.

of LB medium with an appropriate antibiotic. The culture was incubated under shaking for $4 \mathrm{~h}$ at $37^{\circ} \mathrm{C}$, and then transferred into $20 \mathrm{ml}$ of LB medium with antibiotic and again incubated under shaking at $37^{\circ} \mathrm{C}$ until the optical density measured at $600 \mathrm{~nm}\left(\mathrm{OD}_{600}\right)$ reached $\approx 1$. The culture was subsequently aliquoted into sterile Eppendorf tubes $(0.5 \mathrm{ml} /$ tube $)$ and $0.5 \mathrm{ml}$ of $40 \%$ glycerol was added to each tube. The bacterial stocks were stored at $-70^{\circ} \mathrm{C}$. Later, $0.5 \mathrm{ml}$ of the stock was added to $1 \mathrm{l}$ of $\mathrm{LB}$ medium, and $200 \mathrm{ml}$ of the LB medium supplemented with $200 \mu \mathrm{l}$ of ampicillin $(100 \mu \mathrm{g} / \mathrm{ml})$ or $200 \mu \mathrm{l}$ of kanamycin $(50 \mu \mathrm{g} / \mathrm{ml})$ and $100 \mu \mathrm{l}$ of the inoculate was added to a 500-ml flask. The culture was incubated in a rotary shaker at $160 \mathrm{rpm}$ and $37^{\circ} \mathrm{C}$ for $18 \mathrm{~h}$, and then centrifuged at $6000 \mathrm{rpm}$ for $5 \mathrm{~min}$ at $4^{\circ} \mathrm{C}$. The obtained bacterial cell pellet was processed as described in the subsequent section.

Purification of Ub::hGH and cleavage of the fusion protein by deubiquitinating UBPD2C Isolation of inclusion bodies

Wet cell biomass of 5-7 g, obtained from 1 l of culture, was suspended in $100 \mathrm{ml}$ of Buffer C (50 mM Tris $\mathrm{HCl}$, $0.5 \mathrm{M} \mathrm{NaCl}$, and $5 \mathrm{mM} \beta$-mercaptoethanol; $\mathrm{pH} 7.5$ ), and lysozyme was added to a final concentration of $0.43 \mathrm{mg} / \mathrm{ml}$. The suspension was incubated for $35 \mathrm{~min}$ at $20^{\circ} \mathrm{C}$. Then, Triton X-100 was added to a final concentration of $1 \%$ and the mixture was sonicated. Subsequently, phenylmethylsulfonyl fluoride (PMSF) was added to a final concentration of $1 \mathrm{mM}$ and then glycerol followed in a 
quantity corresponding to one-third of the mass of the cell suspension. The mixture was centrifuged at $8000 \mathrm{rpm}$ for $20 \mathrm{~min}$ at $20^{\circ} \mathrm{C}$. The precipitate containing inclusion bodies was suspended in $100 \mathrm{ml}$ of CT buffer (50 mM Tris $\mathrm{HCl}, 0.5 \mathrm{M} \mathrm{NaCl}, 5 \mathrm{mM} \beta$-mercaptoethanol, and $1 \%$ Triton $\mathrm{X}-100 ; \mathrm{pH} 7.5$ ) and sonicated for $10 \mathrm{~min}$ on ice, as previously described [50]. After centrifugation at $8000 \mathrm{rpm}$ for $20 \mathrm{~min}$, the precipitate was suspended in $100 \mathrm{ml}$ of phosphate buffered saline (PBS) with $1 \%$ Triton X-100 and sonicated [50]. The precipitate was centrifuged again and suspended in $100 \mathrm{ml}$ of PBS with $2 \mathrm{M}$ urea, sonicated as reported [50], and centrifuged for another time to obtain the inclusion bodies. The yield of inclusion bodies was between 0.7 and $1.2 \mathrm{~g} / \mathrm{l}$ of culture.

The inclusion bodies were dissolved in DRCI buffer (6-8 $\mathrm{M}$ urea, $50 \mathrm{mM}$ phosphate buffer, and $5 \mathrm{mM} \beta$ mercaptoethanol; $\mathrm{pH}$ 12). The solution was cleared by centrifugation, its $\mathrm{pH}$ was adjusted to 7.0 with concentrated phosphoric acid, and was subsequently loaded onto DEAE Sepharose fast flow (FF) column (approximately $100 \mathrm{ml}$; GE Healthcare Life Sciences) equilibrated with 6-8 $\mathrm{M}$ urea and $20 \mathrm{mM}$ phosphate buffer at $\mathrm{pH}$ 7.0. The flow through material, containing the Ub:: $\mathrm{hGH}$ protein, was collected and the fusion protein was loaded onto SP Sepharose FF column.

\section{SP Sepharose FF column}

The pooled Ub::hGH peak fractions from the DEAE Sepharose FF column were directly loaded onto a 30-ml column filled with SP Sepharose FF (Amersham Pharmacia Biotech $\mathrm{AB}$ ) equilibrated with 6-8 $\mathrm{M}$ urea and $20 \mathrm{mM}$ phosphate buffer at $\mathrm{pH}$ 7.0. The flow through material, containing the Ub::hGH protein, was collected and renatured. Separation on this column was not necessary if the Ub::hGH protein yield from the DEAE column was about $70 \%$.

\section{Renaturation}

Ub::hGH in fractions from the SP Sepharose FF column was renatured by approximately 10 -fold dilution in BR buffer (20 mM phosphate buffer $\mathrm{pH} 7.0,50 \mathrm{mM} \mathrm{NaCl}$ ) to a concentration of $0.09-0.15 \mathrm{mg} / \mathrm{ml}$ protein and then incubated for $1 \mathrm{~h}$ at room temperature.

\section{Ammonium sulfate precipitation}

After renaturation, the fusion protein was precipitated by adding ammonium sulfate to $80 \%$ saturation at $4^{\circ} \mathrm{C}$ under constant stirring. The samples were centrifuged at $12000 \mathrm{rpm}$ for $15 \mathrm{~min}$ at $4^{\circ} \mathrm{C}$. The pellet was suspended in $1 / 40$ th of the pre-centrifugation sample volume (approximately $50 \mathrm{ml}$ ) of $20 \mathrm{mM}$ phosphate buffer ( $\mathrm{pH} 7.5$ ) and $0.5 \mathrm{M} \mathrm{NaCl}$, and then centrifuged at $12000 \mathrm{rpm}$ for $15 \mathrm{~min}$ at $4^{\circ} \mathrm{C}$.

\section{Cleavage of Ub::hGH fusion protein using UBPDC, UBPD2C protease}

The supernatant (protein in $20 \mathrm{mM}$ phosphate buffer $(\mathrm{pH} 7.5)+0.5 \mathrm{M} \mathrm{NaCl})$ was incubated with appropriate DUB preparations to cleave the Ub moiety from the growth hormone polypeptide. The reaction was performed at $37^{\circ} \mathrm{C}$ for $1 \mathrm{~h}(1 \mu \mathrm{l}$ of UBPD2C $60 \mu \mathrm{g}$ of protein; $1 \mu \mathrm{l}$ of UBPDC $-14 \mu \mathrm{g}$ of protein). Then, the sample was centrifuged at $12000 \mathrm{rpm}$ for $15 \mathrm{~min}$ at $4^{\circ} \mathrm{C}$. The supernatant was fractionated by chromatography on Phenyl Sepharose FF resin. The purification process of UBPD2C and UBPDC proteases has been described elsewhere $[19,47]$.

\section{Phenyl Sepharose FF column}

Approximately $20 \mathrm{ml}$ of Phenyl Sepharose FF column (GE Healthcare Life Sciences) was equilibrated with $0.5 \mathrm{M} \mathrm{NaCl}$ and $20 \mathrm{mM}$ phosphate buffer ( $\mathrm{pH}$ 7.0). The hGH protein was eluted with a $3 \mathrm{mM}$ phosphate buffer at $\mathrm{pH}$ 7.0-9.0. The fractions containing the growth hormone were collected, and the protein solution was adjusted to $\mathrm{pH} 7.0$ using concentrated phosphoric acid and stored at $4^{\circ} \mathrm{C}$.

\section{Q Sepharose FF column}

The growth hormone fractions from Phenyl Sepharose FF column were concentrated on a 10-ml Q Sepharose FF column (Amersham Pharmacia Biotech AB). The carrier was equilibrated with $20 \mathrm{mM}$ phosphate buffer at $\mathrm{pH} 7.5$, transferred to the column, and eluted with a linear gradient of $0.5 \mathrm{M} \mathrm{NaCl}$ in $20 \mathrm{mM}$ phosphate buffer (growth hormone containing fractions were eluted at $0.25 \mathrm{M} \mathrm{NaCl})$.

\section{Storage}

The purified growth hormone was transferred into $3.1 \mathrm{mM} \mathrm{Na}_{2} \mathrm{HPO}_{4}$ (pH 7.0; by hydrophobic interaction chromatography, carrier: Phenyl Sepharose FF, isocratic distribution) for storage at $4{ }^{\circ} \mathrm{C}$.

\section{Verification of plasmid stability in cultures grown in LB medium without antibiotic}

One stock was inoculated into $50 \mathrm{ml}$ of antibiotic-free LB medium. The culture was incubated under shaking at $37^{\circ} \mathrm{C}$ until an $\mathrm{OD}_{600}$ of $\sim 1$ was reached. Subsequently, $1 \mathrm{ml}$ of the culture was used for successive passages. Four passages were carried out for each culture for $18 \mathrm{~h}$, and 1-ml samples were collected to obtain bacterial lysates. The Ub::hGH gene expression was verified in the host cells. The experiment was repeated four times independent of the transformation phase, and the accuracy of the results was confirmed. 


\section{Densitometric analysis using Scangel v. 1.45 program} Quantitative analyses of the proteins $\mathrm{Ub}: \mathrm{hGH}, \mathrm{Ub}$, and hGH were performed by staining with $0.05 \%$ Coomassie Brilliant Blue R250 and obtaining electropherograms using the software package Scangel v. 1.45 program (Kucharczyk T.E., Warsaw, Poland). For destaining, the gels were incubated in the same solution without the dye.

\section{Biological activity assay method}

The hGH biological activity assay in the $\mathrm{Nb}-2$ rat cell line was carried out as described previously [51,54-56]. $\mathrm{Nb}-2$ is a prolactin-related cell line sensitive to hGH (somatotropin; European Collection of Cell Cultures (ECACC)). The Nb-2 cells were prepared for the hGH assay as described by Tanaka et al. [57]. After a 24-h incubation period, the cells were suspended at a concentration of $1 \times 10^{5} \mathrm{cell} / \mathrm{ml}$ in RPMI-1640 medium containing $10 \%$ horse serum, glutamine, antibiotic, and 2 -mercaptoethanol. Subsequently, $100 \mu \mathrm{l}$ of the suspension were added to each well of a 96-well cell culture plate, flat bottom (Nunc).

\section{hGH standard solution}

Somatotropin (2.0 IU/mg protein specific activity (SIGMA S-4776)) was used as the standard for hGH biological activity assay. The somatotropin solution was distributed onto a plate with $\mathrm{Nb}-2$ cells so that its concentrations on the plate were $0.004,0.008,0.015,0.03,0.06,0.12,0.265$, $0.53,0.8,1.07$, and $1.33 \mathrm{ng} / \mathrm{ml}$. Six replicates were assayed for each somatotropin concentration.

\section{Preparation of dilutions of the test hGH preparation}

The growth hormone protein concentration in the test preparation was assayed at a wavelength of $280 \mathrm{~nm}$, considering the amount of tyrosine, tryptophan, and cysteine in the hGH. Solutions of the growth hormone preparation were distributed onto a plate with $\mathrm{Nb}-2$ cells in six replicates. The scheme of solutions distribution and their concentrations were similar to those employed for somatotropin, the commercial marker of hGH.

\section{Absorbance reading}

The plates were incubated for $72 \mathrm{~h}\left(37^{\circ} \mathrm{C}, 5 \% \mathrm{CO}_{2}\right)$. Subsequently, $15 \mu \mathrm{l}$ of MTT solution (5 mg MTT/1 ml of PBS) were added to each well, and the plates were incubated for $3 \mathrm{~h}$ at $37^{\circ} \mathrm{C}$. Then, $60 \mu \mathrm{l}$ of lysis buffer $(10 \%$ Triton X-100, $0.2 \mathrm{~N} \mathrm{HCl}$, and 20\% isopropanol) were added to each well and gently stirred. After that, $50 \mu \mathrm{l}$ of DMSO were added and the plates were incubated for $0.5 \mathrm{~h}$ at $37^{\circ} \mathrm{C}$. The absorbance was read with an ELISA plate reader ( $\mu$ Quant Bio-Tek Instruments) at two wavelengths: 585 and $655 \mathrm{~nm}$. The somatotropin standard curves and hGH activity were determined using the $\mathrm{KC}$ Junior software program.

\section{Abbreviations \\ aa: Amino-acid residue; bp: Base pair(s); DUB: Deubiquitinating protease; IPTG: Isopropyl- $\beta$-D-galactoside; hGH: Human growth hormone; kDa: Kilodalton; LB: Luria-Bertani; PCR: Polymerase chain reaction; IU: International unit; UB: Ubiquitin; UBP: Ubiquitin-specific processing protease; SDS: Sodium dodecyl sulfate; SDS-PAGE: Sodium dodecyl sulfate-polyacrylamide gel electrophoresis.}

\section{Competing interests}

The authors declare that they have no competing interests.

\section{Authors' contributions}

$A P, G P$ and $P B$ conceived the project and designed research. AWK, IS, MS, DM, LChP, NL, AMR, ABK, AM, AJP, LG, JKS and RW performed the experiments. AP, GP, AWK and IS analyzed the data. ABK performed MALDITOF mass spectra of hGH (data not shown) and revised the manuscript. GP and PB contributed reagents/materials/analysis tools. AWK wrote the first draft of the manuscript. IS, AJP contributed to the writing of the manuscript. All authors read and approved the final manuscript.

\section{Acknowledgments}

We thank Jacek Skowronski, Departments of Molecular Biology and Microbiology and Pharmacology, Case Western Reserve School of Medicine, Cleveland, Ohio, for critical reading of the manuscript and editorial help.

\section{Funding}

This work was supported by the European Union Project Innovative Economy POIG 01.01.02-00-007/08-00.

\section{Author details}

${ }^{1}$ Institute of Biotechnology and Antibiotics, Staroscinska 5, Warsaw 02-516, Poland. ${ }^{2}$ Department of Pharmaceutical Microbiology, Medical University of Warsaw, Oczki 3, Warsaw 02-007, Poland.

Received: 3 March 2014 Accepted: 27 July 2014

Published: 27 August 2014

\section{References}

1. Tobias JW, Varshavsky A: Cloning and functional analysis of the ubiquitinspecific protease gene UBP1 of Saccharomyces cerevisiae. J Biol Chem 1991, 266:12021-12028.

2. Yu HA, Kim SG, Kim E, Lee WJ, Kim DO, Park K, Park YC, Seo JH: Characterization of ubiquitin C-terminal hydrolase 1 (YUH1) from Saccharomyces cerevisiae expressed in recombinant Escherichia coli. Protein Expr Purif 2007, 56(1):20-26.

3. Waugh DS: Making the most of affinity tags. Trends Biotechnol 2005, 23(6):316-320.

4. Malakhov MP, Mattern MR, Malakhova OA, Drinker M, Weeks SD, Butt TR: SUMO fusions and SUMO-specific protease for efficient expression and purification of proteins. J Struct Funct Genomics 2004, 5(1-2):75-86.

5. Butt TR, Edavettal SC, Hall JP, Mattern MR: SUMO fusion technology for difficult-to-express proteins. Protein Expr Purif 2005, 43(1):1-9.

6. Fong BA, Wu WY, Wood DW: The potential role of self-cleaving purification tags in commercial-scale processes. Trends Biotechnol 2010, 28(5):272-279.

7. Lu Q: Seamless cloning and gene fusion. Trends Biotechnol 2005, 23(4):199-207.

8. Hannig G, Makrides SC: Strategies for optimizing heterologous protein expression in Escherichia coli. Trends Biotechnol 1998, 16(2):54-60.

9. Wang T, Evdokimov E, Yiadom K, Yan Z, Chock PB, Yang DC: Biotin-ubiquitin tagging of mammalian proteins in Escherichia coli. Protein Expr Purif 2003, 30(1):140-149.

10. Costa SJ, Almeida A, Castro A, Domingues L, Besir H: The novel Fh8 and H fusion partners for soluble protein expression in Escherichia coli: A comparison with the traditional gene fusion technology. Appl Microbiol Biotechnol 2013, 97(15):6779-6791.

11. Baker RT, Varshavsky A: Inhibition of the $\mathrm{N}$-end rule pathway in living cells. Proc Natl Acad Sci U S A 1991, 88(4):1090-1094.

12. Baker RT, Catanzariti AM, Karunasekara Y, Soboleva TA, Sharwood R, Whitney S, Board PG: Using deubiquitylating enzymes as research tools. Methods Enzymol 2005, 398:540-554. 
13. $X u X$, Jin F, Yu X, Ren S, Hu J, Zhang W: High-level expression of the recombinant hybrid peptide cecropinA(1-8)-magainin2(1-12) with an ubiquitin fusion partner in Escherichia coli. Protein Expr Purif 2007, 55(1):175-182.

14. Baker RT, Smith SA, Marano R, McKee J, Board PG: Protein expression using cotranslational fusion and cleavage of ubiquitin. Mutagenesis of the glutathione-binding site of human Pi class glutathione S-transferase. J BiO Chem 1994, 269(41):25381-25386.

15. Baker RT: Protein expression using ubiquitin fusion and cleavage. Curr Opin Biotechnol 1996, 7(5):541-546.

16. Pilon AL, Yost P, Chase TE, Lohnas GL, Bentley WE: High-level expression and efficient recovery of ubiquitin fusion proteins from Escherichia coli. Biotechnol Prog 1996, 12(3):331-337.

17. Wang A, Clapper J, Guderian JA, Foy TM, Fanger GR, Retter MW, Skeiky YA: A novel method for increasing the expression level of recombinant proteins. Protein Expr Purif 2003, 30(1):124-133.

18. Catanzariti AM, Soboleva TA, Jans DA, Board PG, Baker RT: An efficient system for high-level expression and easy purification of authentic recombinant proteins. Protein Sci 2004, 13(5):1331-1339.

19. Wojtowicz A, Mazurkiewicz-Pisarek A, Plucienniczak G, Mikiewicz-Sygula D, Chojnacka L, Lukasiewicz N, Plucienniczak A: Expression of yeast deubiquitination enzyme UBP1 analogues in E. coli. Microb Cell Fact 2005, 4(1):17

20. Wójtowicz A, Mikiewicz Syguła D, Płucienniczak G, Płucienniczak A: A UBP1 protease mutant, and its coding sequence, their application and methods of production. In W02004/097011. 2004.

21. Zuo X, Li S, Hall J, Mattern MR, Tran H, Shoo J, Tan R, Weiss SR, Butt TR: Enhanced expression and purification of membrane proteins by SUMO fusion in Escherichia coli. J Struct Funct Genomics 2005, 6(2-3):103-111.

22. Lewis UJ, Sinha YN, Haro LS: Variant forms and fragments of human growth hormone in serum. Acta Paediatr Supp/ 1994, 399:29-31.

23. Ikehara M, Ohtsuka E, Tokunaga T, Taniyama Y, Iwai S, Kitano K, Miyamoto S, Ohgi T, Sakuragawa Y, Fujiyama K, Ikari T, Kobayashi M, Miyake T, Shibahara S, Onot A, Uedat T, Tanakat T, Babat H, Mikit T, Sakurait A, Oishi T, Chisaka O, Matsubara K: Synthesis of a gene for human growth hormone and its expression in Escherichia coli. Proc Natl Acad Sci U S A 1984, 81:5956-5960.

24. Isaksson OG, Eden S, Jansson JO: Mode of action of pituitary growth hormone on target cells. Annu Rev Physiol 1985, 47:483-499.

25. Garcia-Barros M, Costoya JA, Rios R, Arce V, Devesa J: N-glycosylated variants of growth hormone in human pituitary extracts. Horm Res 2000, 53:40-45.

26. Olson KC, Fenno J, Lin N, Harkins RN, Snider C, Kohr WH, Ross MJ, Fodge D, Prender G, Stebbing N: Purified human growth hormone from E. coli is biologically active. Nature 1981, 293(5831):408-411.

27. Persson J, Andersen DC, Lester PM: Evaluation of different primary recovery methods for $E$. coli-derived recombinant human growth hormone and compatibility with further down-stream purification. Biotechnol Bioeng 2005, 90(4):442-451.

28. Dagnaes-Hansen F, Holst HU, Søndergaard M, Vorup-Jensen T, Flyvbjerg A, Jensen UB, Jensen TG: Physiological effects of human growth hormone produced after hydrodynamic gene transfer of a plasmid vector containing the human ubiquitin promotor. J Mol Med (Berl) 2002, 80(10):665-670. Epub 2002.

29. Mehta A, Hindmarsh PC: The use of somatropin (recombinant growth hormone) in children of short stature. Paediatr Drugs 2002, 4(1):37-47. Review.

30. Climent V, Marín F, Picó A: Pharmacologic therapy in growth hormone disorders and the heart. Curr Med Chem 2007, 14(13):1399-1407.

31. Breederveld RS, Tuinebreijer WE: Recombinant human growth hormone for treating burns and donor sites. Cochrane Database Syst Rev 2012, 12:CD008990. Review.

32. Herndon DN, Pierre EJ, Stokes KN, Barrow RE: Growth hormone treatment for burned children. Horm Res 1996, 45(Suppl 1):29-31. Review.

33. Rojas Y, Finnerty CC, Radhakrishnan RS, Herndon DN: Burns: an update on current pharmacotherapy. Expert Opin Pharmacother 2012, 13(17):2485-2494

34. Kim MJ, Park HS, Seo KH, Yang HJ, Kim SK, Choi JH: Complete solubilization and purification of recombinant human growth hormone produced in Escherichia coli. PLoS One 2013, 8(2):e56168.

35. Salamone D, Barañao L, Santos C, Bussmann L, Artuso J, Werning C, Prync A, Carbonetto C, Dabsys S, Munar C, Salaberry R, Berra G, Berra I, Fernández N, Papouchado M, Foti M, Judewicz N, Mujica I, Muñoz L, Alvarez SF, González E,
Zimmermann J, Criscuolo M, Melo C: High-level expression of bioactive recombinant human growth hormone in the milk of a cloned transgenic cow. J Biotechnol 2006, 124(2):469-472.

36. Patra AK, Mukhopadhyay R, Mukhija R, Krishnan A, Garg LC, Panda AK Optimization of inclusion body solubilization and renaturation of recombinant human growth hormone from Escherichia coli. Protein Expr Purif 2000, 18(2):182-192

37. Liu X, Chen Y, Wu X, Li H, Jiang C, Tian H, Tang L, Wang D, Yu T, Li X: SUMO fusion system facilitates soluble expression and high production of bioactive human fibroblast growth factor 23 (FGF23). Appl Microbiol Biotechnol 2012, 96(1):103-111.

38. Khan MA, Sadaf S, Sajjad M, Waheed Akhtar M: Production enhancement and refolding of caprine growth hormone expressed in Escherichia coli. Protein Expr Purif 2009, 68(1):85-89.

39. Koo TY, Park TH: Expression of recombinant human growth hormone in a soluble form in Escherichia coli by slowing down the protein synthesis rate. J Microbiol Biotechnol 2007, 17(4):579-585.

40. Hondred D, Walker JM, Mathews DE, Vierstra RD: Use of ubiquitin fusions to augment protein expression in transgenic plants. Plant Physiol 1999, 119(2):713-724.

41. Butt TR, Khan MI, Marsh J, Ecker DJ, Crooke ST: Ubiquitin-metallothione in fusion protein expression in yeast. A genetic approach for analysis of ubiquitin functions. J Biol Chem 1988, 263(31):16364-16371.

42. Ecker DJ, Stadel JM, Butt TR, Marsh JA, Monia BP, Powers DA, Gorman JA, Clark PE, Warren F, Shatzman A, Crooke ST: Increasing gene expression in yeast by fusion to ubiquitin. J Biol Chem 1989, 264(13):7715-7719.

43. Butt TR, Jonnalagadda S, Monia BP, Sternberg EJ, Marsh JA, Stadel JM, Ecker DJ, Crooke ST: Ubiquitin fusion augments the yield of cloned gene products in Escherichia coli. Proc Natl Acad Sci U S A 1989, 86(8):2540-2544.

44. European Pharmacopoeia 7th edition. Strasbourg: European Directorate for the Quality of Medicines and Healthcare, Council of Europe; 2011.

45. The United States Pharmacopeia, USP 35, NF 30, United States Pharmacopeial Convention, Rockville, MD 20852. 2011:1991.

46. Nguyen MT, Koo BK, Thi Vu TT, Song JA, Chong SH, Jeong B, Ryu HB, Moh SH, Choe $\mathrm{H}$ : Prokaryotic soluble overexpression and purification of bioactive human growth hormone by fusion to thioredoxin, maltose binding protein, and protein disulfide isomerase. PLoS One 2014, 9(3):e89038.

47. Wojtowicz A, Mazurkiewicz-Pisarek A, Chojnacka L, Płucienniczak A: A UBP1 protease mutant, and its coding sequence, their applications and heterogonous protein expression system. In Patent WO 2006/ 073320 A1. 2006.

48. Mikiewicz D, Wróbel B, Wegrzyn G, Płucienniczak A: Isolation and characterization of a ColE1-like plasmid from Enterobacter agglomerans with a novel variant of rom gene. Plasmid 1997 38(3):210-219.

49. Zaleski P, Wawrzyniak P, Sobolewska A, Mikiewicz D, Wojtowicz-Krawiec A, Chojnacka-Puchta L, Zielinski M, Plucienniczak G, Plucienniczak A: New cloning and expression vector derived from Escherichia coli plasmid pIGWZ12: A potential vector for a two-plasmid expression system. Plasmid 2012, 67(3):264-271.

50. Plucienniczak A, Sokołowska I, Marciniak-Rusek A, Łukasiewicz N, Smorawińska M, Chojnacka L, Płucienniczak G, Mikiewicz-Syguła D, Kuthan J, Kruszyńska A, Wolinowska R, Strzeżek K, Wójtowicz A, Mazurkiewicz-Pisarek A, Wójcik E: Method for production of recombinant growth hormone in form of hybrid protein. In US Patent. 2011:892787.

51. Valentin-Hansen $P$, Aiba H, Schumperli D: The structure of tandem regulatory regions in the deo operon of Escherichia coli K12. EMBO J 1982, 1:317-322.

52. Lim D, Maas WK: Reverse transcriptase-dependent synthesis of a covalently linked, branched DNA-RNA compound in E. coli $B$. Cell 1989, 56(5):891-904.

53. Brosius J, Holy A: Regulation of ribosomal RNA promoters with a synthetic lac operator. Proc Natl Acad Sci U S A 1984, 81(22):6929-6933.

54. Denizot F, Lang R: Rapid colometric assay for growth and survival. Modification to the tetrazolium dye procedure giving improved sensitivity and reliability. J Immunol Methods 1986, 89(2):271-277.

55. Goodwin CJ, Holt SJ, Downes S, Marshal NJ: The use of intermediate electron acceptors to enhance MTT bioreduction in microculture tetrazolium assay for human growth hormone. Life Sci 1996, 59(20):1745-1753. 
56. Goodwin CJ, Holt SJ, Riley PA, Downes S, Marshal NJ: Growth hormoneresponsive DT-diadhorase-mediated bioreduction of tetrazolium salts. Biochem Biophys Res Commun 1996, 226(3):935-941.

57. Tanaka T, Shiu RP, Gout PW, Beer CT, Noble RL, Friesen HG: A new sensitive and specific bioassay for lactogenic hormones: measurement of prolactin and growth hormone in human serum. J Clin Endocrinol Metab 1980, 51(5):1058-1063.

doi:10.1186/s12934-014-0113-4

Cite this article as: Wojtowicz-Krawiec et al:: Use of Ubp1 protease

analog to produce recombinant human growth hormone in Escherichia coli. Microbial Cell Factories 2014 13:113.

\section{Submit your next manuscript to BioMed Central and take full advantage of:}

- Convenient online submission

- Thorough peer review

- No space constraints or color figure charges

- Immediate publication on acceptance

- Inclusion in PubMed, CAS, Scopus and Google Scholar

- Research which is freely available for redistribution 